\title{
FENOMENA KORUPSI DI INDONESIA; Perspektif Hukum Pidana Islam
}

\author{
Ahmad Zikri \\ UIN Sultan Syarif Kasim Riau \\ Jl. H. R. Soebrantas, KM. 15, Simpang Baru Panam-Pekanbaru \\ Email: azikrihassan@gmail.com
}

\begin{abstract}
Abstrak
Masib tingginya kasus tindak pidana korupsi menunjukkan pemberantasan korupsi belum maksimal. Salah satu faktor penyebabnya adalah lemahnya bukuman yang diberikan kepada pelaku tindak pidana korupsi. bukuman diberikan mempunyai tujuan pemidanaan sebagai Preverensi Khusus bagi pelaku tindak pidana untuk tidak mengulangi perbuatannya dan Prevefensi Umum selain pelaku agar tidak melakukan tindakan serupa. Lebih lanjut, bukuman bagi pelaku tindak pidana korupsi belum mampu memberikan efek jera. Bentuk. bukuman dan ukurannya dalam bukum pidana islam diserabkan kepada hakim karena ini dikategorikan kepada Ta'žir. Akan tetapi lebih baik jika dilakukan formulasi dalam sebuah Qanun. Hukum pidana islam memberikan porsi yang besar kepada Hakim dalam pemberian bukuman bagi pelaku tindak pidana sehingga menimbulkan disparitas putusan
\end{abstract}

Kata Kunci: korupsi, pidana islam, ta'?irir

\begin{abstract}
Still a criminal act of corruption corruption has not been maximal. One of the contributing factors is weakness corruption. Punishment given has the purpose of punishment as a special preference for the perpetrator a criminal offense for his actions and the General Preference other than perpetrators so as not to carry out similar acts. Furthermore, the perpetrator of the crime corruption has not been able to provide a deterrent effect. Shape and its size in criminal law is left to the judge because of this categorized to Ta'zir. However, it is better if the formulation is done in a Qanun. Islamic criminal law provides a large portion to Judges in giving crimes for criminals so creates disparity in verdicts
\end{abstract}

Keywords: forest and land fires, islamic criminal law, ta'rir

\section{PENDAHULUAN}

Korupsi bukan lagi sebuah kejahatan yang biasa, dalam perkembangannya korupsi telah terjadi secara sistematis dan meluas. Korupsi telah menimbulkan efek kerugian negara dan dapat menyengsarakan rakyat. Karena itulah korupsi kini dianggap sebagai kejahatan luar biasa (extra ordinary crime).

Kejahatan korupsi telah disejajarkan dengan tindakan terorisme. Secara definitif banyak pengertian yang diberikan oleh para pakar diberbagai bidang pengetahuan. Sebagai upaya untuk memberikan pemahaman tentang korupsi, baik dalam bidang sosiologi, psikologi, politik dan juga hukum. Akan tetapi apapun pengertian yang diberikan oleh para pakar hanyalah memberikan gambaran dari sudut pandang masing-masing, pada akhirnya pengertian secara hukum pidanalah yang dijadikan sebagai alat untuk memberantas tindakan korupsi.

Secara etimologis, korupsi berasal dari kata korup yang berarti buruk, rusak dan busuk, korup juga berarti dapat disogok melalui kekuasaan untuk kepentingan pribadi. ${ }^{1}$ Korupsi juga disebutkan dari bahasa latin corrumpere dan corruptio yang berarti penyuapan dan corruptore yang berarti merusak. istilah ini kemudian dipakai dalam

1 Tim Penyusun Kamus Pusat Bahasa Depdikbud, Kamus Besar Bahasa Indonesia, (Jakarta: Balai Pustaka, 1998), hlm. 527 


\section{NUSANTARA; Journal for Southeast Asian Islamic Studies}

Vol. 15, No. 1, Juni 2019

berbagai bahasa asing seperti bahasa inggeris menjadi corruption atau corrupt belanda menjadi corruptie atau kormptie dan di Indonesia menjadi korupsi. ${ }^{2}$

Dalam kamus arab modern kata corruption di terjemahkan dengan fasad atau ifsad. ${ }^{3}$ Menurut Mahmud Muhammad secara istilah fasad adalah: Setiap kejahatan dan pelanggaran yang bertentangan dengan bukum Islam, tujuan, dan aplikasinya disebut dengan fasad. ${ }^{4}$

Berangkat dari pengertian tersebut juga memperhatikan pengertian dari korupsi yang dikemukakan oleh para ahli, pada prinsipnya tidak terdapat perbedaan antara pengertian syari dan pengertian yang lain tentang korupsi yang intinya adanya kepentingan umum yang dirugikan, yang dilakukan oleh public officier atas wewenangnya sebagai pelayan kepentingan umat. Karena dimana ada maslahat disitu ada syariat allah.

Menurut beliau korupsi yang dilakukan oleh pejabat publik dan aparatur pemerintah lainnya adalah perbuatan fasad yang disebut dengan fasad idari atau administrative corruption, ${ }^{5}$ Berdasarkan pengertian diatas dipahami bahwa perilaku public officier yang keluar dari ketentuan hukum, tujuan, dan penerapan hukum Islam yang berkaitan dengan wewenang atau tugasnya sebagai pelayan kepentingan umum.

Masih menurut beliau bahwa praktek fasad idari yang paling banyak terjadi yaitu risywah (suap), pencopetan(takblis) dan pemalsuan (t'a $i r){ }^{6}$

Samuel Huntington dalam bukunya political order in changing societies mendefinisikan korupsi

2 Evi Hartati, Tindak Pidana Korupsi, (Jakarta: Sinar Grafika, 2005), hlm.8-9

${ }^{3}$ Lihat, Corruption ; Decay ; Decomposition ; Degeneration ; Disintegration; Putrefaction ; Putridity ; Rot ; Rottenness ; Spoiledness, Http://Www.Almaany.Com/Ar/Dict/Ar-; Lihat Juga Hans Wehr, A Dictionary Of Modern Written Arabic, (New York: Spoken Langguage Service. Inc, 1976), hlm. 712

${ }^{4}$ Mahmud Muhammad, Alfasad Alidari Wa Ilajubu Fi Syariat Al Islami, (Yordania: Daar Al Tsaqafah, 2011), hlm. 74

${ }^{5}$ Ibid
${ }^{6}$ ibid sebagai behaviour of public official with deviates from accepted norms in order to serve private ends. ${ }^{7}$

Melihat definisi tersebut jelas bahwa korupsi tidak hanya menyangkut aspek hukum, ekonomi dan politic tetapi juga menyangkut perilaku manusia yang menjadi bahasan utama serta norma yang diterima dan dianut masyarakat.

Definisi korupsi di atas mengidentifikasikan adanya penyimpangan dari pegawai publik dari norma-norma yang diterima dan dianut masyarakat dengan tujuan mendapatkan keuntungan pribadi (serve private ends). Senada dengan azyumardi azra, beliau mengutip

The abuse of public or private office for personal gain. corruption involves behavior on the part of officials in the public and private sector, in wich the improperly and unlawfully enrich themselves and/ or those close to them, or include others to do so, by missusing the position in wich they are placed. ${ }^{8}$

Penyalahgunaan jabatan publik atau swasta untuk keuntungan pribadi Definisi yang lebih menyeluruh adalah sebagai berikut: Korupsi mencakup perilaku pegawai sektor publik dan swasta, dimana mereka secara tidak pantas dan melawan hukum memperkaya diri mereka sendiri dan/atau orang-orang yang dekat dengan mereka, atau membujuk orang lain untuk melakukan hal tersebut, dengan menyalahgunakan jabatan dimana mereka ditempatkan.

Dari definisi diatas terdapat unsur-unsur yang melekat pada korupsi pertama, tindakan mengambil, menyembunyikan menggelapkan harta negara atau masyarakat, kedua melawan norma-norma hukum yang sah dan berlaku, ketiga penyalahgunaan kekuasaan atau wewenang atau amanah yang ada pada dirinya keempat, demi kepentingan diri sendiri, keluarga kerabat korporasi atau lembaga instansi, kelima, merugikan pihak lain baik masyarakat atau negara. Penipuan, penggelapan dan cara-cara kotor dalam mendapatkan harta secara tegas dilarang di dalam

\footnotetext{
7 Samuel Huntington, Political Order In Changing Societies, (New York: 1968), hlm. 59

8 Asian Development Bank, Anticorruption: Our Framework Polices and Strategyies, hlm. 9-10.
} 
Islam sebagaimana, berbuat) dosa, padahal kamu mengetahui. (Q.S. Al-Baqarah: 188).

Ayat lain yang mempunyai arahan yang sama untuk tidak berbuat fasad juga Allah Jelaskan dalam Alqur'an Surat Al-'Araf ayat 56 Allah berfirman:

dan janganlah kamu membuat kerusakan di muka bumi, sesudah (Allah) memperbaikinya dan Berdoalah kepadaNya dengan rasa takut (tidak akan diterima) dan harapan (akan dikabulkan). Sesungguhnya rahmat Allah Amat dekat kepada orang-orang yang berbuat baik (QS. Al-A'raf:56)

Korupsi merupakan perbuatan terlarang yang hukumnya haram. Untuk menentukan korupsi sebagai sebuah jarimah dibutuhkan ijtihad didalam sumber hukum Islam baik dalam AlQur'an, Al-Sunnah, Ijma' dan Qiyas sebagai sumber hukum yang disepakati oleh para ulama atau dari sumber hukum yang para ulama masih berbeda pendapat sebagai sumber hukum Islam seperti istishab, istislah, urf dan yang lainnya.

Ijtihad dalam menetapkan korupsi sebagai suatu tindak pidana tidaklah berhenti pada menetapkan korupsi sebagai perbuatan yang hukumnya haram. Akan tetapi juga harus ditetapkan apakah hukuman yang diberikan kepada pelaku tindak pidana korupsi dalam hukum Islam, begitu juga berat dan ringannya hukuman yang diberikan. Praktik koruptif dalam hukum Islam atau hukum pidana telah ada sejak masa Nabi Muhammad saw masih hidup. Hanya saja jika dilihat dari praktik yang ditempuh oleh nabi lebih dominan pada aspek pembinaan moral. Artinya nabi tidak memperlakukan praktik korupsi dalam ranah jarimah (kriminalisasi).

Uqubah (hukuman) itu adalah pembalasan yang telah ditetapkan demi kemaslahatan masyarakat atas pelanggaran perintah pembuat syariat (Allah dan RasulNya). 'Uqubah atau sanksi hukuman dalam sistem hukum pidana Islam terbagi kepada tiga kategori utama yaitu 'uqubah hudud, "uqubah qishash dan diyat dan 'uqubah ta'zir.

9 Ahmad Wardi Muslich, Pengantar dan Asas Hukum Pidana Islam, (Jakarta: Sinar Grafika, 2006), hlm. 49
Perbedaan antaranya adalah, 'uqubah hudud, qishash dan diyat ditentukan jelas oleh nash alQur'an dan sunnah. Sedangkan 'uqubah ta'zir ditentukan oleh pemerintah. Hukum pidana Islam sebagai realisasi dari hukum Islam itu sendiri, menerapkan hukuman dengan tujuan untuk menciptakan ketentraman individu dan masyarakat serta mencegah perbuatan yang bisa menimbulkan kerugian terhadap masyarakat, baik yang bisa menimbulkan kerugian terhadap jiwa, harta, maupun kehormatan. Hukuman yang ditegakkan dalam syariat mempunyai dua aspek: Preventif dan Refresif dengan diterapkannya kedua aspek tersebut, akan dihasilkan satu aspek kemaslahatan yaitu terbentuknya moral yang dilandasi nilai agama akan membawa perilaku manusia sesuai dengan tuntunan agama.

\section{Hukuman Bagi Pelaku Tindak Pidana Korupsi Dalam Perspektif Hukum Pidana Islam}

Sanksi tindak pidana korupsi dalam hukum pidana Islam pendekatannya melalui pendekatan ta'zir. ta'zir merupakan konsep yang fleksibel dan dinamis dalam merespon perubahan zaman. Hal inilah yang dipahami oleh pakar hukum pidana Islam mengapa sanksi dalam pidana ta'sir diserahkan kepada wali al-amri (pemerintah) untuk urannya.

Dalam beberapa hadith Nabi saw. Hukuman yang diberikan lebih dominan pada penekanan pembinaan moral (tidak mengkriminalisasikan), yaitu dengan ancaman hukuman ('uqūbat) tidak dishalatkan jenazah koruptor, dan mendapat siksa neraka di akhirat. Hal ini karena jumlah nominal harta ghulūl yang dikorupsi relatif sangat minim (kurang dari tiga dirham), yakni berupa mantel dan seutas atau dua utas tali sepatu. Akan tetapi seandainya pada masa itu jumlah yang dikorupsi mencapai puluhan juta atau ratusan juta, maka Nabi Saw. Pasti menerapkan hukuman ('uqübat) yang lebih keras dan berat. Karena Rasūlullāh Saw. merupakan sebagai pemegang tasyrī',jelas mempunyai kekuasaan dan kewenangan untuk pembentukan perundang-undangan hukum Islam terhadap suatu permasalahan baik secara individu maupun secara institusi kolektif.

Harus dipahami bahwa sanksi pidana ta'zir tidaklah ditentukan, pemerintah boleh melakukan 


\section{NUSANTARA; Journal for Southeast Asian Islamic Studies}

Vol. 15, No. 1, Juni 2019

ijtihad untuk menentukan jenis hukuman dan kadarnya sesuai dengan pertimbanganpertimbangan yang dimilikinya. Kemaslahatan umum dalam hukum Islam mendapatkan porsi yang tinggi. Sehingga setiap bentuk perbuatan yang berdampak pada kemaslahatan umum dapat diberikan hukuman yang berat. Dengan demikian sangat mungkin terjadi perubahan bentuk hukuman terhadap para koruptor dalam perspektif hukum pidana Islam. jika korupsi masuk dalam ranah ta'sir maka semua bentuk hukuman dalam ta'íir dapat dijatuhkan kepada pelaku tindak pidana korupsi.

Dengan konsep ta'zir bentuk hukuman ('uqubat) nya lebih bervariatif dan sistematis, sesuai dengan tingkat kejahatannya. Bervariasinya bentuk hukuman ('uqubat) tersebut karena tidak adanya nash qath'i yang berkaitan dengan tindak kejahatan yang satu ini (korupsi). Artinya sanksi syari'at yang mengatur hal ini bukanlah merupakan paket jadi dari Allah swt. yang siap pakai. Melainkan sanksi dalam perkara korupsi termasuk sanksi ta'sir , di mana seorang hakim (imam/pemimpin) diberi otoritas penuh untuk memilih tentunya sesuai dengan ketentuan syari'at bentuk sanksi tertentu yang efektif dan sesuai dengan kondisi ruang dan waktu, di mana kejahatan tersebut dilakukan.

Ibnu Qoyim berkata dalam kitabnya alHudud wa at Ta'zir, beliau mengklasifikasikan hukuman ta'zir bagi pelaku kemaksiatan sebagai berikut: ${ }^{10}$

1. Hal-hal yang berkaitan dengan badan seperti dengan cambukan dan pembunuhan.

2. Hal-hal yang berkaitan dengan harta seperti dengan perusakan dan penyitaan.

3. Hal-hal yang berasal dari keduanya seperti dicambuknya pencuri barang yang tidak terjaga bersama dengan penyitaan atas barang curian tersebut.

4. Hal-hal yang berkaitan dengan membatasi ruang gerak seperti dengan penahanan dan pengasingan.

5. Hal-hal yang berkaitan dengan moral seperti penjatuhan harga diri berupa celaan dan pengusiran.

${ }^{10}$ Bakr bin Abdullah Abu Zaid, al-Hudud wa at-Ta'sir at 'Inda Ibnu Qoyim, (Riyad: Dar as-Shimah, $1415 \mathrm{H}$ ), hlm. 484
Hukuman-hukuman ta'sir banyak jumlahnya, yang dimulai dari hukuman paling ringan sampai hukuman yang terberat. Hakim diberi wewenang untuk memilih diantara hukuman-hukuman tersebut. ${ }^{11}$ Sementara tentang batasan dalam $t a^{\prime} z i r$ menurut jumhur ulama tidak terdapat batasan maksimum maupun minimum. Hakim berhak menentukan hukuman dan kadarnya menurut pertimbangan dalam ijtihadnya, akan tetapi manakala pemerintah telah menetapkan batasan baik maksimum maupun minimumnya maka tidak ada jalan lain bagi hakim kecuali mengikuti batasan yang telah ditetapkan oleh pemerintah. ${ }^{12}$

Penetapan sanksi tindak pidana korupsi dalam perspektif hukum pidana Islam dapat dilakukan oleh pemerintah. Proses ini dilakukan sebagai bentuk ijtihad yang dilakukan oleh pemerintah. Pemerintah boleh menetapkan secara bersama-sama dengan ablu al hali wa al-aqdi melalui musyawarah. Bahkan menurut abu zahrah pemerintah harus melakukan hal tersebut bersama dengan ablu al halli wa al-aqdi yang menyiratkan bahwa kekuasaan pemerintah bukanlah kekuasan dari dirinya sendiri, kekuasaan itu juga bukan suatu warisan yang diperolah dari orang tuanya tapi kekuasaan pemerintah

${ }^{11}$ Abdul Aziz Amir membagi dalam 11, yaitu bagian 1. hukuman mati; 2. hukuman jilid 3. hukuman penahanan 4. hukuman pembuangan 5. hukuman ganti rugi 6 . hukuman publikasi dan emanggilan paksa 7. hukuman berupa nasehat 8 . hukuman berupa pencelaan 9. hukuman berupa pengucilan 10.hukuman berupa pemecatan 11 . hukuman berupa penyiaran ; Abdul Muhsin AlTariqi dalam 6 bagian 1. hukuman mati2. hukuman pembuangan/ pengasingan 3. Hukuman pencelaan 4. Hukuman pengucilan 5. hukuman penyiaran 6. hukuman nashat; Wahab Al Zuhaili dalam 5 bagian 1. hukuman pencelaan 2. hukuman penahanan 3. hukuman pemukulan 4. hukuman ganti rugi materi 5 . hukuman mati karna pertimbangan politik; Abdul Qadir Audah dalam 15 bagian 1. hukuman mati 2. hukuman jilid 3. hukuman penahanan 4. hukuman pengasingan 5 . hukuman salib 6 . hukuman berupa nasehat 7. hukuman pengucilan 8 . hukuman berupa pencelaan 9. hukuman berupa ancaman 10. hukuman penyiaran 11 . hukuman pemecatan 12. Hukuman pembatasan hak 13. hukuman penyitaan aset kekayaan 14 . hukuman perampasan benda-benda tertentu milik pelaku 15 . hukuman ganti rugi dan denda.

12 Mahmud Muhammad Barkat, Sultoh Taqdiriyah Li Al Qadhi Fi Fiqhi Al Islamy, (Yordania: Daar Nafais, 2007), hlm. 380 
diberikan oleh rakyat melalui musyawarah ablu albali wa al-aqdi.

Produk ketetapan pemerintah ini disebut dengan qanun dimana prosesnya disebut dengan taqnin.17 Konsep taqnin hukum Islam mempunyai hubungan dengan kebijakan politik hukum. hukum Islam tampaknya sangat akomodatif dalam menyikapi perubahan sosial, politik, dan hukum masyarakat. Hasbi AshShiddiqiey telah mengatakan bahwa hukum Islam pada sudut keberlakuannya bersifat progressif dan dinamis. ${ }^{13}$

Fungsi taqnin hukum Islam tidak lain adalah untuk tujuan penegakan hukum Islam. Penegakan hukum Islam merupakan upaya untuk tegaknya atau berfungsinya norma-norma hukum Islam secara nyata sebagai pedoman perilaku dalam kehidupan bermasyarakat dan bernegara. Penerapan hukum Islam yang tidak dinamis adalah tidak akan memiliki masa depan. Tujuan pemidanaan dalam hukum pidana Islam secara umum merupakan bagian dari Tujuan pokok hukum Islam, yaitu mendatangkan, mendapatkan, dan memelihara kemașlahatan bagi manusia, sesuai dengan teori mașlahah dalam konsep maqāsid al-syarı̄ah.

Sementara Ta'zir dalam tinjauan al-maqashid dapat dijelaskan sebagai berikut: ${ }^{14}$

Pertama, Memelihara maqashid dharuriyat, bajjiyat dan tabsiniyat dalam syariat Islam, pelaku tindak pidana menghilangkan salah satu dari maslahat ini yang telah disyariatkan oleh Allah bagi hamba-hambanya. Hukuman tidaklah disyariatkan di dalam Islam melainkan untuk memelihara dan menjaga maslahat ini. Izzuddin bin abdissalam berkata: "bukuman pidana ta'izir menolak mafsadat tindak pidana dia adakalanya memelihara bakbak. Allah swt atau bak-hak hambanya atau bak. Allah dan Hak hambanya bersamaan"

Kedua, Memberikan pelajaran/pendidikan bagi pelaku tindak pidana dan mencegahnya. Pemberian hukuman ta'iir kepada pelaku tindak pidana menghalangi/mencegah mereka melakukan tindak pidana sebagaimana melarang mereka melakukan tindak pidana dan

13 Hasbi As-Shiddiqiey, Dinamika dan Elastisitas Hukum Islam, (Jakarta: Tintamas, 1975), hlm. 27

14 Taha Faris, Maqashid Al-Tasyri' Al-jina'i Fi figh AlIslamy, Makalah Dalam Konferensi Yang Di Laksanakan Di Universitas Alsyariqah Tahun 2008, Hlm. 106-107. mengulanginya serta memelihara syariat dan mengokohkan untuk melaksanakan hukuman dalam memberbaiki dan mendidik mereka. Bukan untuk menyakiti mereka dan melecehkan kemanusiannya serta menghilangkan hak-hak mereka.

Ketiga, Mencegah orang lain yang mempunyai potensial crime melakukan sesuatu yang melanggar hak Allah swt atau manusia dari suatu yang tidak ada hadnya. Orang yang memiliki niat jahat melakukan tindak pidana ta'zir jika mengetahui atau melihat orang yang dihukum ta'zir atas kesalahannya itu dapat menghalanginya melakukan tindak pidana serupa.

Keempat, Menjaga keamanan masyarakat dan tata tertibnya karena tindak pidana ta'sir merusak keamanan dan tata tertib masyarakat hukuman ta'yir memeliharanya memberikan rasa aman terhadap individu dan social dari kejahatan pelaku tindak pidana.

Kelima, Mencegah pelecehan ajaran agama, dasar-dasar dan hukum-hukumnya, melalui penjatuhan hukuman ta'iir kepada orang yang menghina atau melecehkan ajaran agama dan prinsipnya maka orang jahat diberikan pelajaran dengan hukuman yang mencegahnya mengulangi kejahatannya begitu juga mencegah orang lain dari melakukan kejahatan yang sama.

Azumardi Azra sebagaimana dikutip oleh Nurul Irfan menjelaskan bahwa persoalan korupsi tidak bisa diselesaikan dengan tindakan-tindakan normatif semata. Problem korupsi harus di tindak melalui jalur hukum positif yang memiliki daya cengkram dan sanksi yang jelas, tidak cukup hanya ditakut-takuti dengan adanya sanksi neraka terlebih ada sebahagian ulama yang menawarkan konsep sin loundering penyucian dosa hal ini tentu tidak bisa dibenarkan sehingga harus ditindak lanjuti melalui jalur positif. ${ }^{15}$

Formulasi pidana korupsi melalui taqnin, ${ }^{16}$ menjadi salah satu cara yang paling efektif untuk

${ }^{15}$ M. Nurul Irfan, Korupsi dalam Hukum Pidana Islam, (Jakarta:Amzah,2011),hlm. 253

16 Taqnīn berasal dari kata qanūn. Ia berasal dari bahasa Yunani yang masuk menjadi bahasa Arab melalui bahasa Suryani yang berarti "alat pengukur" atau "kaidah". Dalam bahasa Arab kata kerjanya qanna yang artinya membuat hukum (to make law/ to legislate). Kemudian qanūn dapat berarti hukum (law), peraturan (rule/regulation), Undang-undang (statute/code). A.J. Wensink, The Encyclopedia 


\section{NUSANTARA; Journal for Southeast Asian Islamic Studies}

Vol. 15, No. 1, Juni 2019

merepresentasikan tanggungjawab pemerintahan dengan membentuk pranata hukum Islam terhadap pemberantasan korupsi dalam kehidupan masyarakat.

Adapun penerapan sanksi pidana ta' ${ }^{\prime} i r$ bagi pelaku korupsi melalui pendekatan teori ta'îir (nazhariyyah al-ta'zîi), selanjutnya dapat diupayakan dilakukan melalui tiga strategi sebagai berikut: ${ }^{17}$

Pertama, Strategi Preventif. Strategi ini harus dibuat dan dilaksanakan dengan diarahkan pada hal-hal yang menjadi penyebab timbulnya korupsi. Setiap penyebab yang terindikasi harus dibuat upaya preventifnya, sehingga dapat meminimalkan penyebab korupsi. Disamping itu perlu dibuat upaya yang dapat meminimalkan peluang untuk melakukan korupsi dan upaya ini melibatkan banyak pihak dalam pelaksana- anya agar dapat berhasil dan mampu mencegah adanya korupsi.

Kedua, Strategi Deduktif. Strategi ini harus dibuat dan dilaksanakan terutama dengan diarahkan agar apabila suatu perbuatan korupsi terlanjur terjadi, maka perbuatan tersebut akan dapat diketahui dalam waktu yang sesingkatsingkatnya dan seakurat-akuratnya, sehingga dapat ditindaklanjuti dengan tepat. Dengan dasar pemikiran ini banyak sistem yang harus dibenahi, sehingga sistemsistem tersebut akan dapat berfungsi sebagai tata aturan yang cukup tepat memberikan sinyal apabila terjadi suatu perbuatan korupsi. Hal ini sangat membutuhkan adanya berbagai disiplin ilmu baik itu ilmu hukum, ekonomi maupun ilmu politik dan sosial.

of Islam, Jilid IV, (New Ed.), (CD Version), hlm. 558 dan A. Qadri Azizy, Eklektisisme Hukum Islam: Kompetisi Antara Hukum Islam dan Hukum Umum, (Yogyakarta: Gama Media Press, 2002) hlm. 47-56. Secara terminologis, taqnin alahkam berarti mengumpulkan hukum-hukum dan kaidahkaidah penetapan hukum (tasyri')yang berkaitan dengan masalah hubungan sosial, menyusunnya secara sistematis, serta mengungkapkannya dengan kalimat-kalimat yang tegas, ringkas, dan jelas dalam bentuk bab, pasal, dan atau ayat yang memiliki nomor secara berurutan, kemudian menetapkannya sebagai undang-undang atau peraturan, lantas disahkan oleh pemerintah, sehingga wajib para penegak hukum menerapkannya di tengah masyarakat. Mushtafa az-Zarqa, al-Madkhal al-Fiqh al-'Am, Juz 1, Cet. X, (Damascus: Dār al-Fikr, 1968), hlm. 313

${ }^{17}$ Endang Jumali, Penerapan Sanksi Pidana Ta'Zîr Bagi Pelaku Tindak Pidana Korupsi di Indonesia, Jurnal Asy-Syari'ah Vol. 16, No. 2, Agustus 2014, Hlm. 122-123
Ketiga, Strategi Represif. Strategi ini harus dibuat dan dilaksanakan terutama dengan diarahkan untuk memberikan sanksi hukum yang setimpal secara cepat dan tepat kepada pihakpihak yang terlibat dalam korupsi. Dengan dasar pemikiran ini proses penanganan korupsi sejak dari tahap penyelidikan, penyidikan dan penuntutan sampai dengan peradilan perlu dikaji untuk dapat disempurnakan di segala aspeknya, sehingga proses penanganan tersebut dapat dilakukan secara cepat dan tepat. Namun demikian pada tahap implementasinya tentu harus dilakukan secara terintregasi dan sistematis.

Oleh karena itu, pemerintah dalam hal ini harus memiliki komitmen politik yang lebih kuat, menerapkan strategi yang lebih sistematis dan komprehensif. Selain itu, juga perlu dirumuskan berbagai kebijakan yang lebih fokus dan konsolidatif untuk mendorong dan meningkatkan program percepatan pemberantasan korupsi di Indonesia.

Peneliti dapat mengatakan di sini bahwa pemberantasan korupsi di Indonesia melalui penerapan sanksi pidana ta'zîr memerlukan peran serta ulama, ahli hukum, pemerintah, parlemen, dan aparatur penegak hukum itu sendiri. Alasannya, bukan hal yang mudah merubah suatu tradisi hukum lama menjadi tradisi hukum baru. Salah satu strategi yang paling memungkinkan dalah harus dimulai dari kekuasaan itu sendiri, tepatnya dari eksekutif, legislatif, dan yudikatif.

Bahwa hukuman ('uqubat) yang akan ditentukan dan diterapkan bagi pelaku tindak pidana korupsi melalui konsep ta'zīr dapat dikategorikan kepada tiga tingkatan, yaitu:

1. Hukuman ('uqubat) berat (mughalladab), seperti hukuman mati dan penyaliban, yaitu penerapan hukuman yang dilakukan bagi pelaku tindak pidana korupsi di atas Rp. 500.000.000,- (lima ratus juta rupiah);

2. Hukuman ('uqubat) sedang (mutawasitab), seperti hukuman dera, penjara, pembuangan, penyitaan harta, pencopotan jabatan, tidak dapat menjasi saksi, penyebarluaskan berita tindak pidana yang bersangkutan, dan denda. Sanksi ini diterapkan terhadap pelaku tindak pidana korupsi di atas Rp. 50.000.000,- (lima puluh juta rupiah) sampai Rp. 500.000.000,(lima ratus juta rupiah); 
3. Hukuman ("uqubat) ringan (mukhaffafah) seperti hukuman peringatan, ancaman, dan hardikan. Hukuman ini berlaku bagi pelaku korupsi yang nominalnya sangat minim, yaitu antara nol rupiah sampai Rp. 50.000.000,(lima puluh juta rupiah).

\section{Penjatuhan Hukuman bagi Pelaku Tindak Pidana Korupsi dalam Hukum Islam}

Hukuman ta'iir sebagai sanksi pidana tindak pidana korupsi merupakan hukuman yang ghair muqaddarah. Syariat memberikan kewenangan kepada wali al amri (pemerintah) untuk menetapkan hukuman dari sisi bentuk hukuman dan kadarnya. Artinya kewenangan ini ada pada pemerintah. Akan tetapi dalam sejarah hukum Islam, kewenagan pemerintah ini diserahkan kepada qadhi (hakim) karena alasan banyaknya tugas pemerintah dan luasnya daerah pemerintahan yang diemban pemerintah.

Qadhi diberikan kewenangan untuk memutuskan hukuman terhadap suatu perkara yang dihadapkan kepadanya. Tugas hakim dalam menyelesaikan permasalahan yang terjadi ditengah-tengah umat ini ditegaskan di dalam AlQur'an sebagai berikut:

Hai Daud, Sesungguhnya Kami menjadikan kamu khalifah (penguasa) di muka bumi, Maka berilah keputusan (perkara) di antara manusia dengan adil dan janganlah kamu mengikuti hawa nafsu, karena ia akan menyesatkan kamu dari jalan Allah. Sesungguhnya orang-orang yang sesat darin jalan Allah akan mendapat azab yang berat, karena mereka melupakan hari perhitungan. (QS. Shad: 26).

\section{Dalam Ayat yang lain juga disebutkan:}

dan hendaklah kamu memutuskan perkara di antara mereka menurut apa yang diturunkan Allah, dan janganlah kamu mengikuti hawa nafsu mereka. Dan berhatihatilah kamu terhadap mereka, supaya mereka tidak memalingkan kamu dari sebahagian apa yang telah diturunkan Allah kepadamu. jika mereka berpaling (dari hukum yang telah diturunkan Allah), Maka ketahuilah bahwa Sesungguhnya Allah menghendaki akan menimpakan mushibah kepada mereka disebabkan sebahagian dosa-dosa mereka. dan Sesungguhnya kebanyakan manusia adalah orang-orang yang fasik. (QS. Al-Maidah: 49)

Begitu juga dalam sunnah yang menjelaskan tugas hakim adalah sebagai berikut:

Artinya : Dari amr bin ash beliau mendengar rasullullah saw bersabda apabila hakim memutuskan suatu perkara lalu berijtihad dan benar ijtihadnya dia memperoleh dua pahala, dan apabila dia memutuskan perkara lalu berijtihad lantas ijtihadnya salah maka dia memperoleh satu pahala (HR. Bukhari)

Dengan demikian, dalam tindak pidana korupsi penjatuhan hukuman kepada pelaku tindak pidana korupsi ada pada qadhi. dengan ijtihadnya hakim bisa memberikan hukuman apa saja dalam ranah ta'zīr sebagai sanksi tindak pidana korupsi. meskipun demikian tidak berarti qadhi bahwa kewenangan qadhi adalah muthlak. Kewenangan qadhi dalam memutuskan hukuman sanksi tindak pidana korupsi tetaplah harus memperhatikan prinsip-prinsip pemidanaan yang telah digariskan dalam hukum Islam. secara umum hakim dalam memutuskan hukuman harus memperhatikan maqashid syariah. Selain itu juga hakim harus mematuhi pedoman pemidanaan agar hukuman yang diberikan tidak bertentangan dengan hukum Islam. keputusan hakim yang bertentangan dengan hukum Islam dipandang sebagai keputusan yang fasiq atau dzalim.

Dalam proses penetapan sanksi tindak pidana korupsi harus diperhatikan rambu-rambu sehingga sanksi tindak pidana korupsi tidak dipandang sebagai sanksi yang bertentangan dengan hukum Islam. muhammad abu zahrah menjelaskan bahwa sanksi tindak pidana ta'zīr harus memenuhi beberapa ketentuan, sebagai berikut:

1. Bahwa motifasi yang melatarbelakangi hukuman adalah perlindungan kemaslahatan Islam yang telah ditetapkan bukan menurutkan hawa nafsu dan syahwat. Karena hawa nafsu dan syahwat merupakan dua hal yang saling bertentangan yang tidak bisa dipertemukan;

2. Bahwa hukuman yang telah ditetapkan itu efektif memotong kejahatan atau meminimalisirnya. Janganlah hukuman itu menimbulkan kemudharatan atau mafsadah yang mencerai beraikan masyarakat. Hukuman 
tidak boleh merendahkan nilai-nilai kemanusiaan. Hukuman berfungsi untuk meluruskan masyarakat. Tidaklah benar meluruskan itu dengan menghinakan kemanusiannya dan menghilangkannya.

3. Bahwa terdapat kesesuaian/kesetimpalan antara hukuman dan tindak pidana yang dilakukan. tidak diperbolehkan berlebihlebihan dalam hukuman dan tidaklah boleh menurutkan hawa nafsu berdasarkan tindak pidananya. Jika hukuman itu sesuai dengan tindak pidana pelaku pidana akan merasakan keadilannya lalu diapun tunduk atau rela dengan hukuman yang dijatuhkan bahkan sebelum hukuman itu diberikan.

4. Bahwa terdapat persamaan dimata hukum dan keadilan diantara semua orang. Persamaan ini diperintahkan dalam setiap undang-undang (qanun) yang adil. Tidak boleh memberlakukan suatu hukum kepada sekelompok orang dan memberlakukan hukum yang lain kepada kelompok yang lain.

Hal seperti ini adalah bentuk perbedaan yang zalim sementara manusia semua sama di depan hukum sebagaimana sabda nabi muhammad saw bahwa manusia itu sama rata bagaikan gigi sikat rambut (sisir). ${ }^{18}$

Dalam rangka mendapatkan keputusan yang adil dalam hukuman tindak pidana korupsi. hakim harus mempertimbangkan aspekaspek pelaku, tindak pidana korupsi itu sendiri dan aspek social. Dari keputusan hukuman yang dibuatnya.

Konsekuensinya adalah bahwa aspek-aspek tersebut akan menghasilkan keputusan yang berbeda-beda yang dalam hukum positif disebut dengan disparitas hukuman. selama hukuman itu menjunjung tinggi keadilan sebagai substansinya maka dalam perspektif hukum pidana Islam disparitas putusan bukalah suatu yang dipermasalahkan.

Disparitas hukuman ini terjadi karena besarnya kewenangan yang diberikan kepada hakim. Karena belum adanya ketentuan khusus terhadap tindak pidana korupsi dalam sistem

${ }^{18}$ Muhammad Abu Zahrah, Al-Uquubah fi Al-Fiqh AlIslamy, (Mesir: Daar Al-Fikri AlArabiy, 1937), hlm. 70-71 hukum pidana Islam. jika sudah terdapat ketentuan yang mengatur tentang tindak pidana korupsi yang ditetapkan oleh pemerintah dalam sebuah qanun maka hakim harus mematuhi apa yang telah ditetapkan oleh pemerintah. Meskipun dilain pihak adanya qanun mempersempit kewenangan hakim. kewenangan hakim dalam memberikan hukuman tidaklah mutlak tapi terbatas. Terutama dalam keputusan hukuman yang menyangkut nyawa pelaku tindak pidana. bagaimanapun pelaku tindak pidana dalam hukum Islam tetap mempunyai hak-hak yang tidak boleh dilanggar.

Menurut Al-Audah dalam hal ini hakim harus mendapat persetujuan dari pemerintah barulah hukuman dapat diberikan. Dengan demikian, hukuman mati bagi pelaku tindak pidana korupsi meskipun secara syariat diperbolehkan akan tetapi terdapat pengaturan yang ketatat. Terdapat persyaratan yang harus terpenuhi barulah hukuman mati bagi pelaku tindak pidana korupsi dapat diberikan. Jelaslah bahwa Islam sangat memperhatikan kehidupan/nyawa manusia meskipun kepada pelaku kejahatan selama kejahatan itu bukanlah kejahatan pembunuhan yang diberlakukan qisash padanya.

Dalam menjatuhkan hukuman tindak pidana korupsi hakim boleh memberikan lebih dari satu hukuman. ${ }^{19}$ melalui ijtihadnya hakim akan mempertimbangan seberapa efektifkah hukuman itu dapat berfungsi sesuai tujuannya. Jika dinilai satu hukuman belum/tidak mencukupi maka hakim bisa memberikan lebih dari satu hukuman. ${ }^{20}$

\section{Penutup}

Hukuman bagi pelaku tindak pidana korupsi dalam Hukum Pidana Islam mengikuti ketentuan dalam ta'zir. semua jenis hukuman dalam ta'zir secara teoritis dapat dijatuhkan kepada pelaku tindak pidana korupsi meskipun pada tataran praktis masih membutuhkan kajian lebih lanjut oleh pakar hukum pidana islam. Sistem penjatuhan Hukuman bagi Pelaku Tindak Pidana Korupsi dalam hukum islam dapat dilihat

19 Abd al-Qadîr 'Awdah, Al-Tasyri' al-jinâ’i al-Islamî Muqāranah bi al-Qanûn alWad'i, Jilid I, (Bairut: Mu'assāsah al-Risālah, 1997), hlm. 80

${ }^{20}$ Ibid 
Ahmad Zikri: Fenomena Korupsi di Indonesia...

dari dua aspek yaitu pertama, jika ketetapannya telah dibuat dalam bentuk qanun maka hakim harus mematuhi apa yang telah ditetapkan dalam qanun, kedua, jika hukuman itu belum ditetapkan dalam qanun maka hakim mempunyai kewenangan yang luas dalam menetapkan hukumannya sesuai ijtihadnya.

\section{DAFTAR PUSTAKA}

'Abd al-Qadîr 'Awdah, 1987, Al-Tasyri' al-Jinâii alIslamî Muqāranah bi alQanûn al-Wad'ı, Jilid I, Bairut: Mu’assāsah al-Risālah.

Abu Abdullah Muhammad bin Ismail al Bukhari, $1422 \mathrm{H}$, Shahih al Bukhari, Damaskus: Dar Thuq Al Najah.

Ahmad Wardi Muslich, 2006, Pengantar dan Asas Hukum Pidana Islam, Jakarta: Sinar Grafika.

Bakr bin Abdullah Abu Zaid, 1415 H, al-Hudud wa at-Ta'rir at Inda Ibnu Qoyim, (Riyad: Dar as-Shimah.

Endang Jumali, Penerapan Sanksi Pidana Ta'Zîr Bagi Pelaku Tindak Pidana Korupsi Di Indonesia, Jurnal Asy-Syari'ah Vol. 16, No. 2, Agustus 2014,

Evi Hartati, 2005, Tindak Pidana Korupsi, Jakarta:Sinar Grafika.

Hasbi As-Shiddiqiey, 1975, Dinamika dan Elastisitas Hukum Islam, Jakarta: Tintamas.

Hans Wehr, 1976, A Dictionary Of Modern Written Arabic, New York, Spoken Langguage Service. Inc.

M. Nurul Irfan, 2011, Korupsi dalam Hukum Pidana Islam, Jakarta:Amzah.

Mahmud Muhammad Barkat, 2007, Sultoh Taqdiriyah Li Al Qadbi Fi Fiqhi Al Islamy, Yordania: Daar Nafais.

Mahmud Muhammad, 2011, Alfasad Alidari Wa Ilajubu Fi Syariat Al Islami, Yordania: Daar Al Tsaqafah.

Muhammad Abu Zahrah, 1937, Al-Uquubah fi AlFigh Al-Islamy, Mesir:Daar AlFikri AlArabiy.

Syamsul Anwar, 2006, Fikih Anti Korupsi Perspektif Ulama Mubammadiyah Majelis Tarjih Dan Tajdid PP Mubammadiyah, Jakarta:PSAP.

Taha Faris, 2008, Maqashid Al-Tasyri' Al-Jina'i Fi fiqh Al-Islamy, Makalah Dalam 
NUSANTARA; Journal for Southeast Asian Islamic Studies

Vol. 15, No. 1, Juni 2019

Konferensi Yang Di Laksanakan Di

Universitas Alsyariqah.

Tim Penyusun Kamus Pusat Bahasa Depdikbud, 1998, Kamus Besar Bahasa Indonesia, Jakarta: Balai Pustaka. 